\title{
Persistence of African Heritage as an Alternative Path to Development
}

\section{Aondoakaa Utume}

\author{
Dept. of Political Science, Benue State University, Makurdi \\ aondoakaautume@yahoo.com.au/aondoakaautume@bsum.edu.ng
}

\section{Doi:10.5901/ajis.2015.v4n1p81}

\begin{abstract}
As yet, what has been experimented with to achieve development in Africa has yielded nothing other than delusion. Foreign models and theories have been adopted and tried in guiding development programmes of the new states of Africa, thanks to the advice of foreign, especially Western, advisers. The theories and models, which are packages of westernization, have all proved unhelpful, along with the very notions they have engendered among Africans about development. Africa remains underdeveloped and befuddled by the seeming insurmountability of the problem and the contradictory explanations offered by these same foreign experts and some of their African cohorts. Such theories or models have a peculiarity of ignoring the local experiences and, much more, technologies which have largely sustained the people despite the march of modernization. But there might be some lessons to be learnt in this 'persistence of African heritage' if the appropriate understanding of development is to be achieved. It will entail embracing a more culturally autonomous approach to the problem, without necessarily ignoring the gains of modernity, especially in science and technology.
\end{abstract}

Keywords: Africa, Heritage, Development,Modernization,Underdevelopment

\section{Introduction}

The challenge of Africa in the new era is the challenge of mental emancipation, without which we have suffered a lot of confusion even about who we are, and much more, what we are after. Development, as a concept, is popular mainly because of this; but more because we have imbibed the belief and faith in its being the ultimate in all we aspire to. One is not too sure whether we shall ever agree on the true meaning of the term but much less on the approach to achieving it. The failure to appreciate its nature, if not its true meaning, has led to some orchestration of the aforementioned confusion; and in some quarters, this seems a happy thing. As pointed out by Ake (1981), development (as a concept, as a theory, and goal or policy) becomes an instrument in the hands of the manipulators of the exploitative system, both at international and local levels.

Regrettably, this confusion is hardly noticed, even by academics at times, so much that discussion amongst them lives one with only pity for Africa. For a positive way forward, we cannot escape the challenge of providing academic elucidations such that our policy makers can see the way toward the end - the development of Africa. Contrary to Hyden's (1994) distinction between 'auditors' (that is academics) and 'architects' (who are politicians) of development we se see no such clear distinctions; for either group can well play any of the roles. If academic tradition elsewhere prescribes 'auditing' as the main job, in Africa, the urgency of our task determined by the circumstances surrounding our life conditions demand that we face the challenge collectively and concertedly.

There have been fake theories and false starts about development in Africa. It is lamentable that the theories and so the models offered for African development have all along been imported commodities. Indigenous Africanists have had little input into programmes for Africa's development. That Africa has failed to record any appreciable development is hardly blamed on these foreign perceptions of what African development should be, but rather on certain inherent characteristics of African communities themselves. Before now, any conceptual disputations of the foreign submissions were seen as, at best, uncharitable and at worst, ideological misbehavior. The issue was dissolved in ideological differences between the West and the East, or the right and the left. While that continued Africa's development problems were left unattended to or were rendered more complicated.

Discussion of development is timeless; more so in the face of such challenges in the case of Africa. Despite the delusion and confusion, sometimes deliberately diversionary, we cannot drop the term 'development' as suggested by Verhelst (1990, p.63). Substituting a term for 'development' may only amount to another diversionary act. We may thus settle for a more broadly accepted meaning of development that is not just Westernization. This essay, with all modesty, 
aims at attempting just that: by pointing to the confusion, suggesting what should be accepted as true development, and suggesting certain realistic approaches to African development. Such a conception should not ignore the persistence of African heritage that has taken us this far.

\section{Abstracting Development}

We may not have to be detained by the need to pin down a definition of development; a concept whose discussion has become highly polemical, rendering its meaning almost intractable. But as submitted by Verhelst (1990; pp. 10-11), the notion of development being equal to Westernization or modernization is unacceptable. We shall return to that problem later in the discussion.

As already noted, we cannot discuss development without mention of some basic theories advanced in the social sciences; more so as they have affected our attitudes towards the concept and thinking about it. Most popular are the twin European schools of thought i.e. the 'liberal' thinkers, and the Marxists. Representative here might be Talcott Parsons, Walt Rostow, Gabriel Almond on the one hand and Marx himself and Engels on the other. Parsons advanced three sets of pattern variables that distinguish underdeveloped or undeveloped from developed social systems such as particularism of the traditional societies as opposed to universalism of the modern ones; ascriptive as opposed to achievement orientation of the respective different systems; and the diffuseness in functions of the one as opposed to specificity in functions of the other. Rostow on his part identified five stages of development from traditional to pre-take off stage; to take-off; maturity; and mass consumption stages. And Gabriel Almond is popular for his structural-functional approach where he associates structural differentiation and cultural secularization with modernization or development, while structural diffuseness and cultural sacredness is identified with tradition or nondevelopment.

Karl Marx on the other hand had argued in his historical materialism, that humanity, to reach its final destination in the march toward the ultimate stage of development, which is communism, had already passed from primitive communalism, through Asiatic (slave) society, feudalism, and was now at the stage of capitalism, which will inevitably give way to communism. A strand of that argument was his suggestion that capitalism manifested in imperialism (colonialism) was helpful in dragging stagnant societies of Africa, Asia and Latin America into history. In other words, colonialism would export capitalism and help in the bourgeoisization and proletariatization of these foreign lands. It would help them to become like Europe and North America, awaiting communism. The common salient features of these paradigms is that they saw development in unilineal and unidirectional terms, and from a Eurocentric perspective. Reduced to simple terms, being developed means experiencing what Europe has experienced or being like Europe. This line of thinking has been most abused by the so-called modernists submitting absurdities which they consider to be details in conceptualizing development. The following is representative of the material:

It (social development) means a change in the attitudes, values, and expectations of people from those associated with the traditional world to those common to the modern world. It is a consequence of literacy, education increased communications, mass media exposure and urbanization. Secondly, economic development refers to the growth in total economic activity and output of society. It may be measured by per capita gross national product, level of industrialization, and level of individual welfare gauged by such indices as life expectancy, caloric intake, supply of hospitals and doctors, (Huntington, 1968, pp.33-4).

Some such like analyses have included other indices as amount of steel consumed, percentage enrolment of school-age children in schools, number of secondary and tertiary institutions available to a given population, prospects of capital accumulation, birth rates and especially infant mortality rate or general growth rate in population etc. Logic is not lacking to place what and what not under development or underdevelopment.

For Africa, the lessons of Asia (especially China) and Latin America have not discouraged the emergence of another trend in the enterprise - class analysis. These lessons are that the requisite social and economic transformations do not need to wait for the prolateriatization of the peasantry, or the bougeoisization of the feudal or land-owning class. These seem not to have deeply impressed those scholars who insist, perhaps with some good reason, that the national bourgeoisie as a class is to blame for the failings of Africa in its development effort. Along with the new state, the bourgeoisie in Africa has become the obstacle to African development. It has failed to achieve self-emancipation and so continued to mimic the West, rendering itself out of touch with the life expectation of their people. Lacking the power of legitimacy they cannot call upon the people to fully back their development projects; for the people themselves are not interested if not ignorant (Fanon, 1963, Ake, 1981 and Manghezi, 1976). To sum up, there can be no development therefore in a situation where the state is in conflict with the people themselves. The neo-modernists, represented here more by their development agencies also believe in the use of the national elite who might be encouraged to 'develop', 
which development would then 'trickle down' to the mass of the people, (Hyden, 1994, pp.310-311). But rather than development trickling down to the people, theoretical focus tended to move down to the mass of the people. Several factors are reckoned to have been responsible, but how much they have been recognized depends on individuals and their ideological leanings. First, is the historical lesson of the present revolutions in China and Cuba. Next is the lesson of the liberation movements in Portuguese, Africa and Southern Africa which re-emphasize that the major force of social transformation lay not with the bourgeoisie as such, but with the people if only the right messages were sent and were received for that purpose. Last but not the least, and perhaps more fundamental, is the persistence of African heritage. This latter factor is responsible for the recognition of the informal sector, or the 'people's economy.' MacGaffey (1992) has appropriately termed this, 'initiatives from below'. All this in the face of a failed bourgeois-based strategy of development. It is of great significance.

At international level, we can recognize the neo-classists and dependencists on both sides of the divide. The neoclassists derive their arguments mainly from David Richardo's comparative cost advantages theory. Their arguments are rather defensive of international trade, whatever its structure; i.e. that since no country can produce everything it needs, and since countries prefer to produce at the cheapest cost, an international division of labour can be achieved, where countries will produce to exchange at comparative cost advantages, which becomes mutually beneficial to all. Thus, through trade, development could be achieved. This meant that colonies and ex-colonies stood to gain by trade connections. Their current representatives can be said to be protagonists of interdependence. The dependencists can be lumped together with the structuralists. The latter argue, contrary to the neo-classicists' submission on trade and development, that depending on the structure of trade relations, it can increase value for one partner while decreasing same for the other; meaning that while developing one partner to the relationship it is capable of underdeveloping the other. The main thrust of the arguments of the dependencists is that underdevelopment and development are two sides to the same coin. That in the international structure of capitalist economic relations only the centres can achieve development while the peripheries systematically undergo underdevelopment. The reason is that the centres are responsible for the economic systems and institutions both in the centre and at the periphery of which the centre ensures domination. For example, the bourgeoisie responsible for ruling in the periphery are the very creation of the centre and so cannot exercise, and is systematically prevented from exercising, independence from the centre. It cannot, therefore, perform its historical role of leading the way to true development in the periphery. That Dudley Seers and Andre Gunder Frank, leading structuralist and dependencist respectively, happen to have Latin American background is no wonder therefore. In Africa, Samir Amin leads the pack of such political economists (see Blomstrom \& Kettne, 1984). Among Western scholars who see the structure of international capitalism or imperialism (developed over long years of history) as being responsible for the subordinate conditions of the colonies, semi-colonies and ex-colonies are the likes of Harry Magdoff and Johan Galtung, who might be grouped here along with the structuralists and the dependencists.

For Africa, cultural autonomy has not made a very great impact. But from Sheikh Anta Diop's advocacy of African renaissance, i.e. a 'return to Egypt (Chagage, 1994) where he sees ancient Egypt as having contributed to the building of human civilization and which also has something to offer contemporary Africa; and, Davidson's (1991) reminder that African history might have something to offer towards the conceptualization and pursuit of African development, this frame of thinking may soon assume a prominence among Africanists, especially of African stock. As yet the best exponent of this thinking, to our knowledge, is Verhelst (1990), whose analysis covers the entire Third world. Insisting that development cannot be equal to Westenrization, he has used examples, even in Africa, to show how the peasants, least affected by foreign culture are forging ahead with their own know-how as alternatives to, and demonstrating their superiority over, the imported models; more so as these imported models become imposed models without cultural roots in these lands. They (peasants) are ignored philosophically, socially, economically and at times even technologically. This point, though economic, about sums his arguments where he sees the economic philosophies of the Bhudist in Asia, of the Latin Americas and of Africa as being distinct from that of the Euro-Americans.

Basically, there are other economic cultures than those of capitalism or Marxist-Leninsist socialism. Non-Western cultures perceive economy in their own ways. Such cultures are based on the mechanism aimed at maintaining social stability at all cost, on acceptance of hierarchies and respect for the natural order; on a sense of solidarity reinforced by... adherence to a particular lineal, residential or religious group [Verhelst, 1990, p.31].

This model which we prefer to refer to as 'the cultural autonomy model' may be what African development scholars need to consider very seriously while looking ahead. The reason is obvious. Most models have either been tried before without success or have fallen short of meaningful or concrete prescriptions for achieving development. Many others have been plain dishonest, obfuscating and hypocritical, producing delusion rather than development. A cultural autonomy model which does not pretend to unqualified universalism, but is based on the true manifestations of the 
people's feeling and understanding of life, on practical experience of some sort, may fill in an important gap in the development discourse for Africa, and perhaps the rest of the global south. This is where the persistence of African heritage comes in. It must not be ignored if we are honest about achieving development in Africa.

Lastly, we must recognize and acknowledge the great confusion unleashed by a conspiracy of events in world history - the great depression on the one hand, and perestroika and gladnost on the other, with the latter leading to the break-up of the USSR. In the euphoria of ideological triumph, Adam Smith is exhumed and flunged right back into everybody's face by Western scholarship. We are invited to revisit old arguments about the naturalness of the invisible hand in working the economy, whereupon market economy becomes the only panacea to economic underdevelopment. The World bank and the International Monetary Fund (IMF) become the foremost protagonists of the thinking. On the basis of hat, Structural Adjustment Programmes (SAPS) are freely packaged for the Third World and are expected to work miracles, except, again, for the people's culture, their indolence, their illiteracy, their ignorance, their population, their politics, and you know what. But all that if only human rights and democracy are guaranteed, which means individual freedom to do as he likes both economically and politically without government interference except where some vital interest of some multinational is involved. We are advised to have faith and not to mind what all that portends for our future; not to contend with what true democracy may imply for the intentions of capitalist expansion. For, is democracy not the legitimator of all existing inequalities? After all, is it not supposed to be restricted to the ritual of periodic elections on multi-party basis? Nothing new really, except in style. It is globalization; with all its short-comings (Stiglitz, 2002; Bello, 2004; Khor, 2000).

Perhaps a new tactic in neo-colonial operation may achieve what direct colonization failed to achieve for both colonizer and colonized. Many may share in Amin's (1994) skepticism about the prospects of compradorization and recompradorization bringing about the desired development in Africa, or in any part of the global south in the true sense of development.

\section{Mistaken Assumptions; Critiquing the Prevailing Notions}

While we cannot pretend to be capable of offering a totally acceptable definition of development, (what we have tried to avoid till now), it is our considered opinion that we cannot throw any more light on this concept without touching on what we view as mistaken assumptions and notions about it. After all, as acknowledged by Verhelst (1990, p.62), development is a highly charged term which lacks precision. Perhaps that explains why most writers on the concept have hardly attempted any comprehensive or exhaustive definition of the concept. In this regard, modernization as presented by Huntington here, represents also the rest of Western development thought. This quotation from him should be read with 'development' substituting 'modernization'.

At intellectual level, modernization involves the tremendous expansion of man's knowledge about his environment and the diffusion of this knowledge throughout society through increased literacy, mass communications, and education. Demographically, mass modernization means changes in the patterns of life, a marked increase in health and life expectancy, increased occupational, vertical and geographical mobility, and, in particular, the rapid growth of urban population as contrasted with rural. Economically, there is diversification of activity as a few simple occupations give way to many complex ones; the level of occupational skill rises significantly, the ratio of capital to labour increases; subsistence agriculture gives way to market agriculture; and agriculture itself declines in significance compared to commercial, industrial, and other non-agricultural activities. There tends to be an expansion of the geographical scope of economic activity and a centralization of such activity at the national level with the emergence of national market, national resources of capital, and other national economic institutions (Huntington, 1968, pp.32-33).

This sounds like an elaboration of Parson's pattern variables i.e. enumerating those factors that set the West apart and qualifying them as development. Another Western scholar, Walinsky, even in talking about economic development easily succumbs to the same assumptions:

In Asia, and now in Latin America and Africa, the countries and peoples of the less developed world have embarked, or are about to embark, on the quest for economic development. They more desire the benefits development as brought to the more advanced countries - better education, health and housing; the substitution of mechanical power for human toil; industrial facilities, processes and products; improved transportation and communications; diversification and increased economic stability; prestige in the international community. (Walinsky, 1963, p.3)

Some of the mistaken assumptions and notions of development are contained or implied in the above quotations, which both the liberal and leftist scholars are guilty of. We have already observed the West's obsession with all humanity moving their way, thus proclaiming a monism that is development. It is the path to 'the end of history' (Fukuyama, 2006). 
No room is made for variety. This assumed unilinearism presupposes a definite sign-post for development - one which perhaps the West has reached and is awaiting the arrival of the rest of humanity. It remains another thing to convince even the most naïve in the West that the ultimate in development has already been captured by humanity. But this thinking persists that easily produces the categories of developed and less developed without one for 'over-developed'. Some of the absurdities as indices of development should help us out. Thus, communities exceeding in their average consumption of what is an established minimum should be considered over-developed. To take a hypothetical case, a country attains a 1:1 doctors-population ratio...! Such a place should definitely be considered over-developed. Or supposing that a country records a hundred percent school enrolment for school age children, not minding the nature of institutions, the facilities in them and rate of drop out; nor the usefulness of the products of these institutions, would it be qualified for development or over-development'. The other side of it, if by some technological ingenuity the Japanese have managed to reduce the amount of steel consumed, substituting with other fabrications, she should be rendered automatically underdeveloped for recording a low rate of steel consumption compared with Germany, USA or Russia. How about that?

In our undergraduate days, the Kofyar people in Plateau State of Nigeria were reported to have one of the highest calorie intakes in the world in our Anthropology lessons. We have a developed community in them therefore, using the calorie intake index! What is clear, is that the determination of development by how much or less some resources are being consumed in a place misses the point. But, despite the dishonest and fatuous nature of these assumptions, they have succeeded in giving wrong notions of development, creating the 'catch-up' syndrome among African, Asian and Latin American countries.

Similarly, capital formation strategy and improved rate of growth of the Gross Domestic Product (GDP) are misleading. Mechanistically, and keeping faith with foreign models and advisers, some African governments have worked hard and actually recorded improvements in their savings and the GDP only to record no improvement in the life conditions of their people. The South Commission sums up the argument thus:

The declared purpose of development was the eradication of poverty, ignorance, and disease. A large number of developing countries adopted as models developed countries which had by and large banished those evils. And as these countries appeared to set great store by the rate of GDP growth, most countries of the South tended to use it as the yardstick of performance. Increases in the rate of GDP growth became almost a goal in themselves; for practical purposes they came to define development. Most developing countries failed to see that such figures could conceal the poverty, suffering, and injustices that were the very ills they were eager to cure... (South Commission, 1990, p.37).

It must also be questioned the moral justification or rationality of setting and judging development standards of others for them. What obtains in the situation is that any modest or even major achievements are discounted or disregarded. So much so that even miracles are not permitted to occur in Africa, except 'juju', 'voodoo', or 'black magic'. The effect of all that is that, those responsible for decision making, the new 'educated' elite who have usurped the apparatus of decision making (the new state and its bureaucracy) are properly dissuaded from having confidence in anything attempted endogenously. Thus cultural autonomy is effectively blocked and local development enterprise remains hamstrung. While this happens, many more from the West make a career of 'helping' Africa out as development experts and advisers.

True development is "an overall social process which is dependent upon the outcome of man's efforts to deal with the natural environment" (Rodney, 1872, p.12). Recognizing change as the only permanent thing, development as a 'process' presupposes a sustainable change in man's life conditions which is closely tied to his ever present effort to improve these life conditions within the limits of his personal capacity and those of the environment. The laws of 'demand' and 'supply' are constantly at play in this context, i.e. of how much the environment can supply to the demands of man's needs. A given community or society is thus developed relative to how much resources (material and human) it can muster from its environment to meet the needs of its members. Given that each environment has its uniqueness, development is supposed to vary from place to place, however, serving to satisfy the needs of man. This is the cultural element, a very significant one, which contemporary thought about development ignores. Development is capable of many variants: African, Asian, American or European. This means that any forces of change, inimical to its selfsustenance, are non-developmental. This is what obtained in lands over which external power and culture were imposed, especially by colonization. Thus it must be recognized that the golden rule of development is self-sustenance. In other words, it is cultural autonomy to pursue man's needs and desires in a given environment without external obstructive intervention. Thus, development is, indeed, cultural dynamics. Given that, the notion that development can take place only with due respect to culture, (South Commission, pp.45and 132) is, in my view, not far reaching enough. Rather true development must be autochthonous to a given culture - i.e. must take root and grow from there. For no development 
grafted upon a given society can take root without the requisite receptibility of its culture.

\section{Development in Africa}

The foregoing points to the fact that efforts at Africa's development, based on the foreign models (right or left) have all proved unsatisfactory. On the whole there have been shifts from one model to the other. Clearly the right recipe has not yet been found. Even then, the very semblance of concern for African development emerged at the end of colonialism.

But as has been rightly observed by some writers, Africa's problems of development are tied in with the history of her contact with the Europeans (Morel, 1969, Rodney, 1972) - the whole long second half of the second millennium. For all these years, what Africa witnessed was a devastation of her very civilization. It is thus unacceptable modesty to suggest, as some are tempted to do, that there was an 'arrest of African development' rather than a destruction of it.

Subsequently it has been one effort or another to keep Africa in that state of destruction without rejuvenation. It is ironical that through this very process of colonial administration and neo-colonial arrangements, people expected development of Africa, when the very essence of imperialist expansion is the systematic dedevelopment of the affected areas. The direct takeover of foreign lands, the robbing of peoples of their wealth and other values such as was common under colonialism, what Morel (1969) terms 'predatory imperialism' was incapable of bringing development to Africa.

The period of independence was when the need for change of tactics became natural. It was not a moral question, but one of realism. What looked like a more 'refined form of domination (still less refined with respect to Africa, Asia and Latin America) was being experimented with by the U.S.A., especially after World War II - through the Marshall Plan.

On top of all that was the emergence of the USSR as a major power with its communist ideology. Direct imperialism at this stage would spell disaster for all. Domination through economic forces and structures was more indirect and so more palatable. The point being made is that independence was never a good-will gesture. If the West had been able to help it, it would not have been granted. Thus, to see political independence as a free ticket to autonomous development is a serious mistake. It is no surprise that no truly independent-minded nationalist was ever tolerated at independence, (if he could not be bought over to the side of the colonial establishment) to succeed the colonial masters. Lumumba's is a good case in point.

It is not surprising therefore that being friends of the West, the first generation of leaders of the new states of Africa could be seen as collaborating with their former colonial masters. It is reasonable to imagine how the foreign European models became so easily acceptable to those leaders. We have already averred to the weakness of these imported models which were for the most part out of touch with the people's experiences and expectations. But the only democracy (by participation) that tells no lie is economic democracy, without which development is mere wishful thinking.

The early era dominated by the modernist economic advisers to the African leaders presumed wrongly that development could be achieved through a model group of elite who needed to be assisted, supported and encouraged from whom the mass of the people would learn. The failure of this approach has led to the conviction that for true development to occur, the people must be fully mobilized and committed to its processes. In other words, any development effort that passes the people by, in which they do not participate as interested parties, cannot see true development.

The realization of this has not helped matters with foreign advisers still in the lead. Several shifts have yet been made, in strategy, toward development. Welfare programmes were advocated as a way of helping the poor masses too to take interest, and possibly to develop, all to no avail. Currently governments, especially under SAP, have been advised to allow private initiative as a strategy for general development; which fits in with the 'market economy' ideological campaign.

Neo-Marxist models have not fared better, mainly because of their failure to come to terms with what exactly is development and the deficiency of their strategy. Preoccupation with socialist revolution without how to start and sustain one in the face of strong ideological opposition has not been helpful. On top of it all, using the existing links in the world economic structure dominated by capitalism, it becomes easy to subvert such regimes that make such efforts. In the same line of thinking it remains to be elaborated, how Amin's (1993) strategy of 'delinking' African (or third World) economies from international capital can be achieved. Failure to provide such details leaves such a suggestion in no better position than those of other neo-Marxists. Perhaps such conceptual deficiencies also explain the failure of revolutionary efforts to achieve development for Africa, where they have been attempted.

We must not forget the African cultural autonomy model which is already making its silent arguments. Thus, while the debate about the Eurocentric models on both sides of the ideological divide raged on, the people of Africa, especially the unaffected or marginally affected or those steadfast in their resolve not to let the African system die, have been 
forging ahead with their own form of development. This is what I call 'the persistence of African heritage'. Despite that many new systems of technology, economy and politics have been packaged and delivered, which either directly or indirectly subvert the indigenous African systems, the latter have survived and/or regenerated. For example, after so many wasteful years of modernist adventure, it is now being acknowledged that indigenous African systems of agriculture have been more efficient than those recommended by foreign 'experts', for those environments (see Verhelst, 1990, pp.33-4; and Green, 1985, p.22). If we must permit any merit in majority, this seems a good case that is that it has been these 'crude ways,' these 'unmodern', traditional systems or technologies that have been able to sustain the greater part of our populations through the centuries. For, how many of us, despite our 'modernity', go on bread, salad, spaghetti or macaroni, or chicken with chips rather than gari, amala, pounded yam or tuwo with egusi or okra soup by the day? How much of the rice, yam and corn we eat comes from large scale mechanized farms? How much of our protein intake comes from the modern sector of production rather than from the traditional sources employing the local skills in hunting, trapping and fishing and animal husbandry? And despite attempts to soak Africa with products of foreign breweries, local brewing thrives and waxes stronger. Similarly with the rising cost of 'modernity' African herbal medicine is being rehabilitated. And, beside the modern public system of economic transactions, Africans have continued to preserve their own traditional modes of production and exchange up to international level, what has been variously termed informal sector or 'second economy', and 'local seeds'. In politics too, it is observed, those who have come to terms with the African heritage are the happier for it. Maganga's (1986) example of Botswana's success with parliamentary democracy and Davidson's (1991, p.16) observation of progress or achievements with purely African initiatives in a number of countries illustrates this point.

We may thus close this section with Davidson's words, for their appropriateness, that: "There are new trends on the scene: that the pre-colonial principles of state craft (and economics) do have relevance. Even so news of them travels slowly; and skepticism, a product of these 'wasted years', remains understandably widespread" (1991, p.16).

\section{Towards an Alternative Path to Development}

We have noted the development efforts of Africa, yet made under the framework of the modern state structures with their corollary of foreign models. We have tried to show the fallacy of the intellectual traditions behind them, especially Eurocentricism and the non-recognition of the cultural ethos of those for whom development is undertaken in other lands.

We have shown the perverseness of some of the associated notions. We also observed the 'Africa-never-die' spirit in our people's way of life, carrying on despite the imported models and succeeding to help themselves in the main, from the rubbles of colonial devastation. For, these indigenous 'traditional' systems, the 'informal sector' or 'second economies' have, in the main kept Africa going more than anything else. They serve as a reminder, and the beginning of their recognition seems to suggest, that the moment of reckoning has come for them. The search for alternative paths to African development now must be considered timely. Efforts, so far, seem to have exhausted the potential for imported models to help Africa. Besides, the conditions call for the fulfillment of Africa's duty to herself - helping herself in a manner nobody else can.

We venture, therefore, to suggest a cultural autonomy model of development for Africa. As a form of cultural renaissance, it entails rediscovering, regenerating, and rededicating ourselves to African civilization in a progressive manner - i.e. reviving the sustainable aspects of her past, such as in medicine, technology, and art. In other words, the best of Africa's historical experiences be taken advantage of and restored to their appropriate place in the march of human civilization. It does not advocate or suggest autarky. The gains of humanity in science and technology be made to serve the African way of life. For example, the benefits of literacy must be seized upon by Africa. Similarly the good ways of Africa, such as her philosophy of consensus rather than division in political contest, of building a moral society, be retained and developed; just as her knowledge in herbal medicine and skills in agricultural production. These may be now appropriately documented and published with the benefits of literacy.

The following may thus be considered as guides to true African development:

(i) First, it must be established whether the appropriate goals of development efforts have been set, and whether they are achievable. That is to say these must be in harmony with the people's experiences and expectations. Inappropriate and unachievable goals of development such as the 'catch up' syndrome engenders are sure ways of courting frustration. Thus, if our priority is not going to the Moon or to Mars, we must first aim at feeding our populations, providing health services, shelter and a healthy environment. We may provide very cheap but convenient means of communication. These are clearly achievable.

(ii) We must guide against the temptation to denigrate certain groups, especially en bloc, in the community. While 
acknowledging that the 'educated elite' remain the most mentally enslaved to foreign culture, they remain unavoidably African, for they cannot help it. But while our village and rural populations have Africanness to offer them, they also have literacy to offer the mass of the people. Under here, the special role of African academics in intellectual production must be acknowledged. Besides, the educated elite, under the going dispensation, remain the main legitimators. In the spirit of "scholar activism" advocated by Saul (2006) the African educated elite must accept responsibility for intellectual leadership to Africa.

(iii) We must recognize that for the urgency of the task, expansion of Africa's functional literacy is a sine qua non; which means Africans must be assisted to leave records of their know-how in whatever they do. The greatest defect of African civilization has been her over-reliance on oral transmission rather than records.

This partially accounts for why some of Africa's achievements have not been given due recognition. Functional literacy will ensure research and growth in African science, technology and art.

(iv) Africans must develop faith in themselves and what they do. To do this, our political leadership, the originators or propagators of public policy, must develop popular participatory mechanisms to ensure the people's support. This becomes the only way of committing them to what the leadership does. Under here too, we must learn to reject any suggestion that failure can be measured by inability to 'be-like' or 'catch up' with, the West, or any particular region of the world.

(v) We must recognize that efforts and ways to development are painstaking. They cannot be obtained cheaply. For, 'nothing good comes easy.' We must thus develop the patience and perseverance, especially in Africa where we must work against odds others were lucky to escape in their march to development, (such as neocolonial subversion and distraction).

(vi) Lastly, we must accept that only Africa can help herself. At this point, Hodder's warning may be most appropriate:

Africans have their own vivid perception of their own problems, as well as their own set of values and priorities, and in the long run are most likely than anyone else to find practical solutions to them. The danger is not that Africans will be unable to find these solutions, but that they will be persuaded, or worse, forced to accept the solutions of others, whether of the West or East. The danger, too, is that African countries will begin to follow the same paths and make the same mistakes as the rest of the world. (Hodder, 1978, p.152).

Unfortunately, some of the mistakes have already been made. But the situation is not hopeless. The embers of hope and renewal still smolder on, through the persistence of African heritage. Thus, Cosmas' philosophical submission becomes a fitting lesson. Verhelst has captured it thus:

Much more than technical, economic, social or political aspects, the real tragedy of underdevelopment is cultural and spiritual in the sense that there is always hope as long as the collective consciousness still exists, even if only potentially, as long as the embers still glow, as long as beneath the ashes of passivity, or resignation and fatalism, there smolders a spark of life which a single breath can revive (Verhelst, 1990, p.61).

(vii) Thus committed, Africans must be wary of obvious distractions. Much of what is now in the Western agenda is made of such stuff. Micro-liberalism is now peddled in that fashion: same-sex marriage and gender advocacy or campaigns are examples, camouflaged in human rights.

These recommendations do not exhaust the possibilities of rational action that can be taken towards achieving development in Africa. These points must be counted among numerous others considered relevant to this cause. It is a modest suggestion and contribution to the necessary African discourse.

\section{References}

Ake, C. (1981), Political Economy of Africa, Harlow: Longman Group Ltd.

Amin, S. (1993), "The Challenge of Globalization: Delinking". The South Centre, Facing the Challenge,( Responses to the Report of the South Commission). London: Zed Books.

-------- (1994), "The Issue of Democracy in Contemporary Third World," in Himmelstrand, U., Kimanjari, K. and Mburugu, E. (eds) African Perspectives on Development. London: James Curry.

Bello, W. (2004), Deglobalization: Ideas for a New World Economy. London: Zed Books Ltd.

Blomstrom, M. and Hettne, B. (1984), Development theory in Transition: The Dependency Debate and Beyond, Third World Responses. London: Zed Books Ltd.

Chachage, C.S.L., (1994), "Discourse on Development Among African Philosophers" in Minnelstrand, U. Kimajanri, K., and Mburugu, E. (1994), (eds) African Perspectives on Development. London: James Curry Ltd.

Davidson, B. (1991), "What Development Model?," in Africa Forum: A Journal of Leadership and Development, Vol.1, No.1.

Faber, M. and Green, R.H., (1985), "Sub-Saharan Africa's Economic Malaise: Some Questions and Answers," in Tore, Rose (ed) Crisis and Recovery in Sub-Saharan Africa. Paris: OECD. 
Fanon, F. (1963), The Wretched of the Earth. New York: Grove Press.

Fukuyama, F. (2006), The End of History and the Last Man. New York: Free Press.

Galtung, J., (1971), "A Structural Theory of Imperialism", Journal of Peace Research, 1971, No.2.

Hodder, B.W., (1978) Africa Today: A Short Introduction to African Affairs. London: Methuen and Co. Ltd.

Huntington, S. (1968), Political Order in Changing Societies. New Haven: Yale University Press.

Hyden, G., (1994) "Changing Ideological and Theoretical Perspectives on Development", in Himmelstrand, U. Kimanjari, K. and Mburugu, E. (1994), (eds) African Perspectives on Development. London: James Curry Ltd.

Khor, M. (20000, Globalization and the South: Some Critical Issues. Ibadan: Spectrum Books Limited.

MacGaffey, J., (1992), "Initiatives from Below: Zaire's Other Bath to Social and Economic Restructuring", in Hyden, G. and Bratton, M. (eds.) Governance and Politics in Africa. Boulder: Lynne Rienner Publishers, Inc.

Maganga, D.M. (1986), "Democracy in African Tradition: The Case of Botswana," in Ronen, D. (ed.), Democracy and Pluralism in Africa. Boulder: Lynne Reinner Publishers, Inc.

Magdoff, H., (1969), The Age of Imperialism. New York: Monthly Review Press.

------- (1978), Imperialism: From the Colonial to the Present. New York: Monthly Review Press.

Manghezi, A., (1976), Class, Elite and Community in African Development. Unddevalla: Bohuns-Leningens.

Morel, E.D. (1969), The Black Man's Burden, (The White Man in Black Africa from the Fifteenth Century to World War I). New York: Monthly Review Press.

Rodney, W. (1972), How Europe Underdeveloped Africa. London: Bougle L'Ouverture Publications.

Saul, J. (2006), Development After Globalization: Theory and Practice for the Embattled South in a New Imperial Age. London: Zed Books Ltd.

South Commission, (1990), The Challenge to the South Commission. Oxford: Oxford University Press.

Stiglitz, J. (2002), Globalization and its Discontents. London: Penguin Books Ltd.

Verhelst, T.G., (1990), No Life Without Roots: Culture and Development. London: Zed Books Ltd.

Walinsky, L.J., (1963), The Planning and Execution of Economic Development. New York: McGraw-Hill Book Company, Inc. 
